\title{
17. Undoing the Psychologizing of the Psychological
}

ARATA HAMAWAKI

Remarks given at a memorial event, "Celebrating the Life and Work of Stanley Cavell," convened in Emerson Hall 105, Harvard University, Saturday, November 10, 2018.

In "Aesthetic Problems of Modern Philosophy," first published in 1965, and later collected in Must We Mean What We Say?, Stanley Cavell wrote:

We know the efforts of such philosophers as Frege and Husserl to undo the "psychologizing” of logic (like Kant's undoing Hume's psychologizing of knowledge): now, the shortest way I might describe such a book as the Philosophical Investigations is to say that it attempts to undo the psychologizing of psychology, to show the necessity controlling our application of psychological and behavioral categories; even, one could say, show the necessities in human action and passion themselves. And at the same time it seems to turns all of philosophy into psychology-matters of what we call things, how we treat them, what their role is in our lives. ${ }^{1}$

Frege, of course, insisted on distinguishing between what is thought in any act of thinking, the content of thought, which he conceived of as having a propositional form, and the thinking of it. A thought is what can be common to different acts of thinking, whether of one's own or of another. It is thus essentially public, essentially shareable, unowned. By contrast the thinking of a thought is necessarily someone's, 
necessarily owned, and so in that sense private. Frege depsychologized logic, by excluding the psychological from it. The logical must bear no trace of the psychological, for if that were not so, there would be nothing that could be true or false-and so no judgment, no belief, no propositional attitude, as thoughts have subsequently come to be called. There would be in Thomas Rickett's memorable words, merely "mooing." The first person is consequently banished from the logical order, for a first person thought is constituted by the thinking of it. But in depsychologizing logic as he did, Frege seemed to have psychologized psychology. Thus, in speaking of the Investigations as undoing the psychologizing of psychology, I take it, Stanley meant that it seeks to undo what Frege did. However, this doesn't mean undoing what Frege undid, that is, erasing the sharp boundary between the logical and the psychological, but rather to not cede the psychological to psychology: what the PI calls for is to further what Frege began, but, as it were, against Frege. In other words, Stanley saw Wittgenstein as reintroducing the first person as essential to the logical order, the order of what we think. ${ }^{2}$

The passage I read above immediately follows a discussion of the part of Kant's third Critique in which Kant introduces the distinction between the beautiful and the agreeable. There, Kant notes, if someone is challenged on her judgment that something is agreeable, it is perfectly appropriate for her to retreat to saying, "well, it's agreeable to me." But if someone is challenged on her judgment that something is beautiful, it would, far from being appropriate, be "laughable" to retreat to saying, "well, it's beautiful for me." "For," as Kant says, "he must not call it beautiful if it merely pleases him.”3 "What," Stanley asked:

are these examples supposed to show? That using a form of expression in one context is all right, and using it in another is not all right. But what I wish to focus on is the kind [my emphasis] of rightness and wrongness invoked: it is not a matter of factual rectitude, nor of formal indiscretion but of saying something laughable, or which would be folly. It is such consequences that are taken to display a difference in the kind of judgment in question, in the nature

2. Although this idea is still somewhat heterodox, there are some recent philosophers who have followed Stanley's lead. These include Sebastian Rödl and Irad Kimhi.

3. Immanuel Kant, Critique of the Power of Judgment, §7. 
of the concepts employed, and even in the nature of the reality the concepts capture. [...] And how can psychological differences like finding something laughable or foolish (which perhaps not every person would) be thought to betray such potent, or anyway, different, differences?4

Rightness and wrongness here are not measured by the norms of truth, meaning or pragmatic appropriateness. And yet, these judgments are not merely a matter of psychology either, even though, as Stanley observed, it can seem that way. There is such a thing as rightness or wrongness here, even though our judgments of rightness and wrongness are necessarily unsponsored in the familiar ways, by sensory evidence, proof, testimony, expertise, and so on. Like judgments of the beautiful themselves, the philosopher who appeals to everyday language "turns to the reader not to convince him without proof but to get him to prove something, test something against himself. He is saying: Look and find out whether you can see what I see, wish to say what I wish to say."5

Philosophical statements, like aesthetic statements, are essentially first personal-are mine to make. And the risk we bear in making them is not the risk of error but the risk of alienation and exposure, the risk of isolation-the discovery that I speak only for myself. What we may find is not that we disagree about a matter of fact, but that we do not share a world. Unlike my relation to the order of facts, I have a world only insofar as I bring it to expression, bring it to words. In that sense, it could be said, "the world is my world." To use Kant's language, such judgments have, or purport to have, necessary universal "subjective validity.” And, according to Stanley, it is only against the background of necessities of this kind that there can be necessities of the logical kind. You might say that it is only against the backdrop of such subjectively universal necessities that propositions have their life, so that it is so much as possible for us to have propositional attitudes. Contra Frege, the domain of the logical cannot be insulated against the first person. (Or, in Kant's terms, reflecting judgment is a necessary condition of determining judgment.)

4. Cavell, "Aesthetic Problems of Modern Philosophy," 90.

5. Ibid., 96. 
Kant famously said, "it must be possible for the 'I think' to accompany all of my representations," thereby affirming that self-consciousness is not something that is opposed to objectivity but is, on the contrary, constitutive of it. I think of Stanley as inheriting, while transforming, Kant's dictum. For Kant the "I think" is the act of theoretical judgment; it is the "I assert" or the "I hold.” For Stanley it would be more appropriate to say, "it must be possible for the 'I voice' or the 'I express' or the 'I appreciate' to accompany all of my representations." Giving voice to one's experience in the relevant sense is a matter of making a claim, but it is not making a factual claim, or even a practical one. It is giving expression to my appreciation of significance; in so doing I am not simply reporting something, but am making a claim on others to appreciate what I do. What is it that calls for appreciation? If I say, for example, "you have to go see this movie," say, Ozu's Late Spring (Banshun, 1949). How are we to understand the "must" here? The "must" is not in a broad sense theoretical-that is, a matter of what one must believe, for if it were, it ought to be possible for me to take another's word on the matter. Nor is the "must" in a broad sense practical, a matter of something I ought to do, for a failure to do it would have to constitute a rift in our relationship, a breach of the mutual trust that is necessary to constitute a community. When I tell a new friend, "you must read Stanley Cavell," I believe that the "must" here is the same as in "you must see Ozu's Late Spring," which is the same "must" as in Rilke's "you must change your life” (from “The Archaic Torso of Apollo”). What calls for appreciation is neither theoretical nor practical, neither factual nor normative, neither cognitive nor conative, but somehow all of these at once. And it is not only that those familiar dichotomies are inadequate to a grasp of the phenomenon; it is that our sense of what calls for appreciation is, you could say, the common root from which the theoretical and practical orders spring and from which they cannot liberate themselves, the pivot on which "the whirl of organism" whirls.

The philosopher's remarks, as the critic's, may not only be met with disagreement but with worse, with complete indifference-with what Kant in the (first edition) Preface of the first Critique called "the mother of chaos and night"-since, unlike the sciences, neither have a guaranteed audience, but this does not render them dependent on individual fancy or whim. Far from it, as Stanley wrote, "philosophy, like art, is, and should be, powerless to prove its relevance; and that says so- 
mething about the kind of relevance it wishes to have. All the philosopher, this kind of philosopher, can do is to express, as fully as he can, his world, and attract our undivided attention to our own."6 It is impossible for me to imagine a philosopher who has expressed as fully as he can his world as did Stanley, and for us all he stands, as a further self, attracting undivided attention to our own-if we could only heed his warm, cheerful, hopeful, patient, invitation.

Like Kant and Wittgenstein, I don't view self-consciousness as a separate topic in philosophy but rather as central to understanding our relation to the world and to others. For both philosophers, the self is not a separate topic of thought-self-consciousness is not a separate content-but constitutes our relation to the world and to others. I believe that seeing how this is so requires unpacking Stanley's elusive but intriguing idea of "undoing the psychologizing of the psychological." Ever since my days as a graduate student, and as an advisee of Stanley's, I have found his work, in this and other respects, to afford the most compelling way of reading Wittgenstein as inheriting Kant's philosophy, and in turn to represent the most compelling way of inheriting and going on from the work of both. He has been a model for me of how to learn from the history of philosophy, how to make it relevant. 